Trabalhonecessário

\author{
Issn: 1808 - 799X \\ ano 11, no $17-2013$
}

Ensaio

\title{
A Estética do Capital e o Mundo das Coisas
}

\author{
Marcelo Micke Doti ${ }^{1}$ \\ marcelo.micke@uol.com.br \\ Darlan Marcelo Delgado \\ darlandelgado@terra.com.br
}

A riqueza das sociedades em que domina o modo de produção capitalista aparece como uma "imensa coleção de mercadorias", e a mercadoria individual como sua forma elementar.

(Marx. O Capital, 1867)

O aumento da quantidade dos objetos é acompanhada por uma extensão da esfera dos poderes a que o homem está sujeito, e cada novo produto representa uma nova possibilidade de trapaça e embuste mútuo. (Marx. Manuscritos Econômico-Filosóficos, 1844)

\section{Resumo:}

O presente ensaio tem como eixo temático de desenvolvimento a concepção de um espaço produzido pelo capital e inundado de coisas. Porém coisas do capital, ou seja, sua objetivação mais espetacular (no próprio sentido de espetáculo), a mercadoria. Esta fere os sentidos de uma forma completamente diferente de outros objetos, pois se carrega de simbologia estética. Isso conduz a uma forma própria de educação do capital, além de outras: a educação estética e sua violência. Entretanto, não se coloca essa problemática sem a devida referência nas relações de classe e os detentores do poder de decisão de como tal estética

1 Professor e pesquisador do Centro Estadual de Educação Tecnológica "Paula Souza" (CEETEPS) na Faculdade de Tecnologia de Mococa (Fatec). Pós-doutor pela UFABC e doutor na área de Planejamento de Sistemas Energéticos pela FEM-Unicamp, mestre em Sociologia pela FCL/Ar-UNESP e graduado em Ciências Econômicas na mesma instituição.

2 Professor e pesquisador do Centro Estadual de Educação Tecnológica "Paula Souza" (CEETEPS) na Faculdade de Tecnologia de Mococa (Fatec). Doutor e Mestre em Educação pela FCL/Ar-UNESP e graduado em Ciências Econômicas pela FEARP-USP.

TrabalhoNecessário - www.uff.br/trabalhonecessario; Ano 11, № 17/2013. 


\title{
Trabalhonecessário
}

Issn: 1808 - 799X

ano 11, no $17-2013$

irá educar centralizando não apenas capital como também a centralização dos sentidos.

Palavras-chave: Estética, Coisas-Mercadorias, Educação

\begin{abstract}
:
This essay is thematic development to design a space produced by capital and flooded with things. But things of capital, ie, its objectification more spectacular (in the proper sense of sight), the merchandise. This hurts the senses in a completely different way from other objects because it is loaded with symbolism aesthetics. This leads to a proper form of education capital, among other matters: aesthetic education and its violence. However, this problem does not arise without proper reference class relations and the holders of power decide how such aesthetic centering will educate not only capital but also the centralization of the senses.
\end{abstract}

Key-Words - Aesthetics, Things-Merchandises, Education 


\section{Trabalhonecessário}

Issn: 1808 - 799X

ano 11, no $17-2013$

\section{Introdução: um mundo de coisas}

A passagem referida como abertura deste ensaio feita por Marx é justamente aquela com a qual se inicia O Capital. É a primeira frase do capítulo um do livro I, "A Mercadoria". O revolucionário e profundamente vigoroso teórico alemão iniciava aí a demonstração da aparência do mundo do capital, sua fenomenologia. Sabia sobre a essencial necessidade de ir descendo da aparência para o reino da produção. Entrar nesse reino pelas mãos de invisível Virgílio e mostrar as profundas forças estruturadoras do capital, da espoliação e do trabalho como dura tortura, infinita destruição da vida.

No entanto, também se colocou outra citação. Trata-se da aparência desse mundo de objetos, coisas, mundo de coisas. Mas não qualquer coisa, despojada de sentido e ingênua, mera coisa a circular inocente pelo mundo. São mercadorias, "esfera dos poderes estranhos", produtora de embustes e, como não deixaria de ser, de ideologia. Sendo a realidade social e material um conjunto complexo de instituições e coisas, todas apresentam-se como linguagens. Porém, no mundo do capital essas são produzidas sob sua lógica e, como tais, uma linguagem própria configurando-se como ideologia, sua própria maneira de produzir o mundo e the dar sentido (FRY, 1978). Significa a existência entre o mundo da produção e das coisas fluidas postas em nosso cotidiano, profunda articulação e sentido. Articulação esta presente como necessidade de acumulação de capital.

A relação entre produção e a estética das coisas como conteúdos postos à sociedade para deliciar-se na forma de lotófagos ${ }^{3}$ é escopo deste ensaio

\footnotetext{
3 "Partiram de imediato e introduziram-se no meio dos Lotófagos./E não ocorreu aos Lotófagos matar os nossos companheiros;/em vez disso, ofereceram-lhes lótus, para que comessem./E quem entre eles comesse o fruto do lótus, doce como mel, /já não queria voltara para dar a notícia, ou regressar para casa;/mas queriam permanecer ali, entre os Lotófagos,/ mastigando o lótus, olvidados do seu retorno." (Odisseia, IX, 91-97).
} 


\section{Trabalhonecessário}

Issn: 1808 - 799X

ano $11, \mathrm{n}=17-2013$

demonstrando que aparência e essência das mercadorias não são casuais, e sim imensa coleção para a reprodução do capital imbuídas de ideologia concentrada na própria matéria das coisas.

Parêntese essencial será posto logo agora. Em hipótese alguma constitui intenção deslindar elos entre as citações de Marx em dois momentos de sua trajetória prático-teórica, a velha e deslocada questão entre o "jovem" e o Marx "maduro". Sobre este tema apenas deixamos evidenciada a falsidade de toda ruptura sem passar pelas cadeias da dialética. Assim: o que há de continuidade entre o "jovem" e o "maduro"? As continuidades são relevantes? Dentro da totalidade estrutural do pensamento de Marx (ou de qualquer autor cuja obra se quer deslindar) os elementos de continuidade e ruptura não dançam um minueto, ou seja, dança não aleatória, porém cuja compreensão exige atenção para não tropeçar ou pisar no pé? Isso constitui toda uma vida de estudo e nosso interesse é apenas usar as citações para fazer outra dança: aquela na qual se interpenetram as forças da produção e da acumulação com as possibilidades de espaços infinitamente multiplicados por coisas deslumbrantes, espaços arrebatados, abastados e abastardados de coisas, excitação dos sentidos. Interessa-nos trazer à baila as dimensões em que se manifestam as articulações entre o capital e a educação estética dele derivada na forma de um mundo pleno de mercadorias e pobre de individualidades, uma vez que a sociedade está imersa no turbilhão de um mundo de coisas rapidamente renováveis e excitáveis.

Não é por outro motivo que Türcke utiliza a metáfora "sociedade da sensação" para fazer referência ao mundo extasiado pela profusão de informação que se origina no mercado - locus sacralizado ${ }^{4}$ da mercadoria e de sua troca - e

\footnotetext{
${ }^{4}$ Enquanto o sagrado foi sendo desalojado, juntamente com a sociedade tradicional précapitalista, o caráter fetichista da mercadoria irrompe juntamente com o capital, sendo sucedâneo daquele na nova sociedade de mercado que venera o valor de troca - literalmente como força divina - em todos os seus valores de uso (TÜRCKE, 2010).
} 


\section{Trabalhonecessário}

Issn: 1808 - 799X

ano 11, no $17-2013$

simultaneamente o retroalimenta. A argumentação de Christoph Türcke está assentada na sua percepção de que

se tudo o que não está em condições de causar uma sensação tende a desaparecer sob o fluxo de informações, praticamente não sendo mais percebido, então isso quer dizer, inversamente, que o rumo vai na direção de que apenas o que causa uma sensação é percebido" (TÜRCKE, 2010, p. 20, grifo do original).

O capital só consegue continuar sua reprodução produzindo em quantidades maiores: mais e mais produção é o sentido de seu destino, o próprio sangue de suas artérias configurando a acumulação crescente de riqueza, enfim seu leitmotiv. Sobre isso, Türcke (2010, p. 240-1) argumenta que a dinâmica de expansão do capitalismo é viciadora, verdadeira compulsão, a qual se configura em seu próprio motor.

Trazendo Lukács à discussão, o qual em toda sua vida perseguiu os rumos da totalidade em Marx, não podemos ignorar as instâncias, os momentos da realidade, cada uma de suas formas de existir. A produção, reprodução e acumulação de riquezas anteriormente referidas não é processo abstrato: trata-se de uma ação de classe, produto de decisões de classes sociais e sua estrutura nas relações sociais e de produção. A reprodução do capital só pode ocorrer pelo manifesto ato de uma decisão de produzir mais e a acumulação é concentrada junto a esta classe decisória de tal forma que se centraliza o poder da riqueza. Portanto, se este ensaio tem uma intenção estética ${ }^{5}$ e caminha no sentido de uma crítica cultural e existencial sob o capital, nem por isso perde seu contato com o fato de que nenhuma sociedade existe no abstrato: é sempre o resultado de determinações e sobredeterminações muito precisas em uma totalidade de relações de classe.

\footnotetext{
${ }^{5}$ Notar que estética tem aqui acepção totalmente diferente do estudo da obra de arte. Procuramos usar o sentido original da palavra que guarda relação com ferir os sentidos, tocá-los, constrangêlos. Ver Houaiss: "aisthétikós,ê,ón 'relativo à percepção'; ver estet(o)-; f.hist. 1881 esthetico. CA 1881." CA = Caldas Aulete.
} 


\section{Trabalhonecessário}

Issn: 1808 - 799X

ano 11, no $17-2013$

Outro fato não deve ser evitado, pelo contrário, devemos enfatizar é que a aparência do mundo não é uma contraposição à sua essência: um é metamorfose dialética do outro e resultado ideológico e cultural em nossa exposição. $\mathrm{O}$ aparecimento de coisas preenchendo os espaços produzidos pelo capital, enfatizamos anteriormente, não é, em primeiro lugar, um jogo casual, não são objetos inocentes: são mercadorias produzidas dentro de uma racionalidade histórica de um lado e instrumental do outro. Logo, objetos dotados de um sentido transcendente em relação aos sentidos da percepção, mercadorias detentoras de uma aparência involucral sutil, porém portadoras da capacidade de embuste.

Um segundo aspecto no qual se percebe a profunda relação entre a aparência e o mundo essencial do capital procede do primeiro. A aparência da mercadoria deve delinear, moldar os sentidos do ser ao qual ela se destina: o passivo consumidor. Passivo esteticamente, pois é a mercadoria que sente por ele. Ela é toda repleta de sentidos e capacidade de excitar ${ }^{6}$. A única atividade do consumidor é sua excitação, sensação do desejo e de estar imerso no mundo das coisas, todo cheio de alegria tanto quanto sua existência é quase náusea (SARTRE, s/d). Para as mercadorias aparecerem assim dotadas de atividade contra a passividade da sensação humana é fundamental fazer surgir no mundo aqueles que pensem como tal ou qual embalagem, tal ou qual produto, suas cores, e tantas e tantas parafernálias. Somente assim pode ocorrer o aguçamento dos sentidos estimulando o consumidor e tolhendo sua ação, roubando sua individualidade. Surgem os designers, publicitários, arquitetos, etc ${ }^{7}$. O processo todo conflui em aumentar a produção, reprodução e acumulação de capital e toda a cadeia estrutural de classes centralizando mais que o poder, centralizando os sentidos humanos: o momento do encantamento não é mais o belo da arte, mas a

\footnotetext{
6 "Antes que os fetiches se tornassem formações substitutivas de objetos de desejo privados, eles foram corporificação do incorpóreo, ou seja, de um excesso de excitação insuportável." (TÜRCKE, 2010, p. 242)

7 "As inúmeras agências da produção em massa e da cultura por ela criada servem para inculcar no indivíduo os comportamentos normalizados como os únicos naturais, decentes, racionais." (ADORNO; HORKHEIMER, 1986, p. 40).
} 


\section{Trabalhonecessário}

Issn: 1808 - 799X

ano 11, no $17-2013$

realização do desejo do consumo. Dose massiva de endorfina, entorpecimento frenético como aquele proporcionado pelas drogas concentradas ${ }^{8}$.

O núcleo duro da produção transmuda-se na maneira pela qual o capital aparece no mundo pela sua forma fenomenológica, a mercadoria. Mas com todos os sentidos inebriados e passivos, apaixonadamente sensíveis apenas para consumir, a mercadoria se transforma em coleção de coisas e mais coisas, mundo e espaço afogados nessas coisas. A sociedade torna-se passiva diante de todas essas coisas nada ingênuas. Podemos perceber a não oposição ou contraposição entre essência e aparência, mas sua interação dialética. Interação distante de ser reino do conceito, claro, e sim processo de transformação do produto do capital em ideologia. A ideologia assume por meio desse caminho da produção da mercadoria posta e pronta no mundo outro patamar além de todos aqueles já consagrados. A mercadoria tornando-se coisa sensível para seres humanos passivos, torna-se linguagem e como linguagem ela vem ao mundo como ideologia. As formas de dominação do capital ampliam seus poderes pelos

\footnotetext{
${ }^{8}$ Há consagrada bibliografia sobre o tema e seria não só desnecessário como exaustivo colocar ela toda. Podemos citar duas fontes como referência aos aspectos relacionados ao mundo no qual as coisas tornam-se vivas contra a pobreza humana e da mercadoria como "projeto estético". Uma delas, claro, é a parte final do capítulo 1 do livro I de O Capital, o famoso trecho dedicado ao fetichismo da mercadoria. A segunda fonte é o livro de Wolfgang Fritz Haug, Crítica da Estética da Mercadoria (HAUG, 1997). Apenas para ênfase nosso acréscimo aqui é levar ao extremo os sentidos da coisa sobre o ser humano até o momento em que ela possui linguagem própria em mundo no qual o espaço foi invadido pelas mesmas. E por esse caminho as mercadorias carregam em si e por si, apenas em seu pouco sutil e nada delicado aparecer no espaço, enorme carga ideológica. Encontraremos estudo que se encontra com nossa abordagem em Jean Baudrillard, O Sistema dos Objetos (BAUDRILLARD, 2006). Para citar autor em campo de abordagem tangencial a este, mas por outro viés, ou seja, o imenso mundo sensacional produzido por todo esse fluxo de coisas, turbilhão frenético de desejo e posse de mais coisas-mercadorias e a exaustão humana diante de tanta linguagem-embuste, exaustão dos sentidos e a busca do entorpecimento como fuga na medida em que a grande maioria das pessoas nada mais tem e seu ter é massacrando por violência estética abordada a seguir temos autor já referenciado no ensaio. Assim segundo Türcke (2010), ao abordar a paulatina ascensão do uso de drogas a partir do momento histórico da violenta expulsão em massa da população do campo, na transição para o capitalismo, o ópio e o haxixe passaram a ser considerados mais oportunos que o álcool pelo fato de que ambos podem produzir estimulação desencadeadora de fantasia, diferentemente deste último (na forma de aguardente, bebidas destiladas), cuja produção e consumo alastraram-se cada vez mais a partir do século XVII, chegando a promover a chamada "epidemia de destilado" na Inglaterra. E as doses dessa forma de entorpecimento só aumentam. Porém esse seria tema, dado o tamanho do comentário, para outro ensaio.
} 
Trabalhonecessário

Issn: 1808 - 799X

ano 11, no $17-2013$

caminhos mais insuspeitos. Por esse motivo a referência à realidade assim construída como resultado ideológico e cultural. ${ }^{9}$

\section{A violência pela educação estética}

O olhar humano está longe de ser um sentido mecânico. Nosso modelo, ou melhor, o modelo herdado de nossa educação formal sempre nos coloca os sentidos humanos como meramente sensíveis: uma reação simples a dado impulso fornecido pelo mundo da matéria real. A luz toca e se reflete nos objetos e fere nosso sentido da visão. Pelas mãos tateamos o mundo e sentimos sua consistência, porosidade, rugosidade. E assim com os demais sentidos. No entanto, trata-se de fantasia de um modelo de entendimento mais do que mecânico: mecanicista ${ }^{10}$. No caso da visão ela é ferida pela luz dos objetos como sentido biológico, mas há outro ferimento: o ferimento mediado pela linguagem e, no mundo do capital, pelos objetos-mercadorias, pois carregados de fantasias.

\footnotetext{
${ }^{9}$ Ver a referência que Marshall Berman faz sobre o turbilhão ao citar logo na introdução de seu livro Tudo que é Sólido Desmancha no Ar Rousseau e a vida em Paris. Turbilhão de coisas e pessoas que se assemelha grandemente com o que vivemos, mas, para nós, em escala exponencialmente elevada devido às mudanças do capitalismo no século XX em especial sua escala global de produção e especulação. Não se deve negligenciar, portanto, o fato da enorme volatilidade do capital financeiro. Em outros termos, o processo de "financeirização" do capital das últimas décadas articulou-se aos deslocamentos produtivos e construção de novos espaços para essa mesma produção interligando milhões de pontos e força de trabalho no planeta dando a esse mundo de turbilhão, a esse mundo de coisas uma dimensão quase infinita e sem precedentes, nauseando a vida.

${ }^{10}$ A crítica ao materialismo mecanicista já foi feita por Marx e com grande propriedade. Ao mesmo tempo Marx enfatizou a necessidade de tirar o lado ativo da ação humana do idealismo e o passivo do materialismo visto em sua forma mecanicista. Veja sobre isso as teses Ad Feuerbach com destaque para a tese I. Ao destacar a ação humana, Marx evidenciava o caminho para 0 entendimento da ação de classes na sociedade. Isso torna a realidade como materialidade construída em todos os seus detalhes, desde as coisas até o espaço em toda a sua complexidade, produtos dessa ação. Sendo produtos da ação de classes a realidade não é passiva para os sentidos e as fórmulas do idealismo e do materialismo mecanicistas caem por terra. A realidade material do mundo construído pelo capital tornando-se ativa como ação de classe traz a linguagem da ideologia como dissemos. Por outro lado os sentidos humanos articulados dialeticamente com essa atividade real tornam-se ativos como fantasia. Para o entendimento do conceito de materialidade e sua significação como importante para entender uma construção socioeconômica ver o capítulo um do livro Sociedade, Natureza e Energia: condições estruturais e superestruturais de produção no capitalismo tardio (DOTI, 2008).
} 


\section{Trabalhonecessário}

Issn: 1808 - 799X

ano 11, no $17-2013$

Temos aqui um "sexto sentido": o sentido da linguagem, a produtora infinita de símbolos e fantasias ${ }^{11}$.

O sentido mais desenvolvido por nós e essencial na própria evolução do Homo sapiens sapiens é o da visão. Sobre esse sentido também reside o escopo do nosso ensaio, pois é a excitação dele para todas as mercadorias o elemento essencial da estética do capital. Nem poderia ser diferente: como sentido mais aguçado na evolução humana e privilegiado ao longo de todo o desenvolvimento social, o conjunto da instrumentalização conceitual do marketing recai sobre o mesmo, ainda que o som e o rádio "tenham tido o seu tempo", e o som ainda seja elemento sub-reptício na intricada operação de sedução para o consumo e transformação deste em puro desejo ${ }^{12}$.

O olhar, posto dessa maneira, não é mecânico. O único mecanismo presente no olhar é, como referido, sua óptica, física objetiva dos olhos como elemento biológico e assim muito diferente do olhar. Este é pura interpretação: o que olha já está olhando para o que deve ser olhado e interpretando o que olha. Pensemos, por ora, na mercadoria corpo.

Esta é uma mercadoria sim sob muitos sentidos e em primeiríssimo lugar como força de trabalho. No entanto, o corpo e a relação com o olhar assumem a forma de mercadoria no fetiche do corpo: são as imagens, filmes, fotografias etc.

\footnotetext{
${ }^{11}$ Está fora de nossos propósitos e intenções abordar o vasto universo da linguagem. Em primeiro lugar pelo fato dos seus muitos sentidos e campos de estudo. Neste caso seria um campo muito próximo ao da semiologia. Mas, em segundo lugar, existe toda a relação entre linguagem e evolução humana, ou seja, capacidade própria imbricada no processo biológico. Entre os vários autores a tratar do assunto pode-se citar Steven Pinker, O Instinto da Linguagem (PINKER, 2004).

${ }^{12}$ Tão somente como curiosidade ver a homenagem feita ao rádio pelo grupo Queen na música Radio Ga Ga (Álbum The Woorks, 1984) quando diz "you had your time, you had the power". Pensar também na essencial trilha musical de filmes, especialmente os atuais filmes de ação e efeitos de computação gráfica gigantesca e de tirar o fôlego nas telas dos cinemas, traço marcante da indústria cultural nos dias atuais. Ainda sobre o rádio, não podemos esquecer o poder de submeter a todos igualmente, na condição de ouvintes, não só aos programas das estações e, assim, à uma homogeneização do "gosto" musical escolhido pela indústria cultural - que transforma a música (e estilos musicais) em mercadoria vendável e rentável -, como também ao bombardeio da publicidade das mercadorias anunciadas nesse meio de comunicação massificado (ADORNO e HORKHEIMER, 1986).
} 


\title{
Trabalhonecessário
}

Issn: 1808 - 799X

ano 11, no $17-2013$

nos quais o corpo é exposto com vastíssimo e amplo destaque para o corpo da mulher. O olhar de um corpo é, neste caso, o despertar da pura libido, um desejo de possuir esse corpo, capturar e captar cada curva e delinear parte por parte. $\mathrm{O}$ ato sexual seria a realização dessa libido, seria a realização da volúpia sensual. Enquanto esse não se dá ou é impossível de se dar por todas as razões impostas - em especial a renúncia permanente - como ato civilizacional, a fantasia do olhar constrói-se como linguagem. A promessa da satisfação não se concretiza, posto que está desde a origem rompida. Esse é o modus operandi da indústria do erotismo.

\begin{abstract}
A indústria cultural não sublima, mas reprime. Expondo repetidamente o objeto do desejo, o busto no suéter e o torso nu do herói esportivo, ela apenas excita o prazer preliminar não sublimado que o hábito da renúncia há muito mutilou e reduziu ao masoquismo. Não há nenhuma situação erótica que não junte à alusão e à excitação a indicação precisa de que jamais se deve chegar a esse ponto. [...] A produção em série do objeto sexual produz automaticamente seu recalcamento. (ADORNO e HORKHEIMER, 1986, p. 131).
\end{abstract}

Impõe-se problemática interessante: essa relação do olhar e do corpo não precisa se dar simplesmente no universo de filmes, fotos, propagandas sensuais cumprindo sua função social do estímulo do desejo. Pode se dar nas ruas quando o olhar vaga transformado em puro flâneur e descobre seus desejos em muitos corpos. Estes, no entanto, já se encontram também paramentados pelas mercadorias e quando não os próprios corpos já foram alterados por cirurgias plásticas para atender aos padrões estéticos veiculados pela indústria cultural e exigindo a adequação do indivíduo. A libido do olhar dirige-se para um corpo mediado pelas roupas, maquiagem, sapatos e a proximidade do espaço levando às possibilidades sub-reptícias dos cheiros ${ }^{13} \mathrm{e}$, raramente, da voz. Esta a única

\footnotetext{
${ }^{13}$ Os cheiros realizados neste caso pelos perfumes e seus frescores. Mas há algo curioso sobre os cheiros: não é possível uma imagem produzir um cheiro. No caso dos perfumes empregam-se as imagens do frescor ou da sofisticação: para cada escala de perfume, ou seja, seu preço e sofisticação, um tipo de propaganda. Para os de alto padrão recorre-se a grandes estrelas ou astros do cinema e da moda. Com as comidas recorre-se à fantasia dos mesmos fazendo o olhar desejar na boca o preparo daquela comida. Note-se que as propagandas usam neste caso o
} 


\section{Trabalhonecessário}

Issn: 1808 - 799X

ano 11, no $17-2013$

portadora dos elementos não necessariamente mercantis ${ }^{14}$. Pode-se imaginar, no entanto, a pura libido do corpo e esquecer suas funções sociais e seus elementos mediadores mercantis. Neste caso a pulsão do prazer seria central e o olhar muito mais que um olhar, seria construção da fantasia.

É hora, porém, de abandonar o prazer sobre os corpos humanos, reais, biológicos e fantasias proporcionadas sobre os mesmos e deixarmos este assunto para a psicanálise do eu. Esta constitui outro momento da análise não enfocado neste ensaio e remete à libido e ao campo de uma antropologia freudiana matéria para discussão do corpo e sua relação com o capital. A realização do prazer pelas palavras, pela masturbação ou pelo ato sexual não constitui objeto deste ensaio. Interessava mostrar o sentido do olhar como sensibilidade construída pela linguagem e por este meio abrir a possibilidade já referida das coisas do mundo ser parte da estética do capital pelas quais se tornam imediatamente condutores de mensagem e, portanto, ideológicos. Diferentemente do olhar do corpo com a possibilidade ainda ativa de desejo e de perscrutação do mesmo, as coisas do capital, os objetos-mercadorias, são os elementos ativos por nós já exposto. Portanto, como já referimos, objetos pensados para possuir dada aparência, determinado conteúdo, personalizado sem a pessoa da individualidade, preenchidos de sutilezas e embuste e tendo para isso os profissionais já delineados para instigar tudo isso ${ }^{15}$.

preparo lento (slow motion) de um lanche ou de uma comida com tal ou qual tempero. O olhar tem tempo de reter na boca a fantasia do sabor. Pensemos nos comerciais de lanches prontos (McDonald's, Burguer King, Subway, etc.). Além disso, no caso dos ditos fast foods temos ainda o perfil daqueles que figuram nas publicidades: jovens, belos, felizes. Não se vende apenas sanduíches, mas antes um estilo de vida. Algo totalmente mais sério do que se pode imaginar e no qual toda essa aparelhagem linguística constrói uma ideologia pelas imagens.

${ }^{14}$ Não devemos nos iludir ao pensar que a voz ao projetar pensamentos seja a fuga, a redenção contra as coisas, contra o pensamento domesticado e tudo o mais. Muito pelo contrário e é aqui que entra a análise do discurso em todas as suas possibilidades, desde o discurso das questões políticas até aos cacoetes culturais. Falas de novela no Brasil são dos cacoetes mais comuns.

${ }_{15}$ Pode-se chamar a esse tipo de profissional em alto escalão das empresas, mas não elite do planejamento do capital, mas muito bem pago pensando para o capital de profissional orgânico em clara alusão ao conceito de intelectual orgânico de Gramsci. São todos aqueles profissionais cuja 


\section{Trabalhonecessário}

Issn: 1808 - 799X

ano 11, no $17-2013$

A violência se mostra através de uma lógica dura, realidade pura e bruta: produção massiva de mercadorias, renováveis, transmutáveis, todos os anos com tecnologias que em nada mudam o substancial. Mas cumprem sua bruteza ao proporcionarem possibilidade de acumular mais e mais capital centralizando os processos decisórios e concentrando a riqueza. Dissemos ser este o meio pelo qual as coisas - parecem gestadas se fossem inocentes ${ }^{16}$ - vêm ao mundo portando sua bela aura, sua chocante beleza e sua sensibilidade ativa na qual o olhar do consumidor só entende o desejo. $O$ desejo do olhar em sua fantasia agora é fantasia pelas coisas e somente realizado pela perversa troca de trabalho por dinheiro e este o meio universal de realizar o seu gozo, gozo mercantil. Imensa articulação dialética se estabelece entre todos os complexos conectados da realidade construída pelo capital: a produção, o trabalho submetido a todas as condições (cada vez mais flexibilizadas; leia-se: direitos trabalhistas destruídos ${ }^{17}$ ), reprodução do capital, acumulação realizada pela inundação de coisas no mundo, embustes e trapaças mediadas pela beleza de seus adornos, promessas de felicidade e prazer, os sentidos subjugados e no final da cadeia de articulações a centralização dessas decisões de um mundo que passa a existir pelo e para o capital. A violência está em toda a imensa articulação dialética, mas consegue seu intento mais extraordinário ao tornar o olhar um plácido e inativo flâneur não mais ao seu bel prazer, mas pelo prazer de submeter o desejo ao capital. A estética do capital como forma de educação está completa.

função é modelar e construir os projetos da elite. No caso abordado neste ensaio, são os profissionais da imagem e sua plasticidade fantasmagórica.

${ }^{16}$ Pode-se fazer pequeno paralelo sobre a "inocência" das coisas, ou melhor, a inexistência de sua inocência com Lukács em $A$ Destruição da Razão (LUKÁCS, 1972). Sendo em si, pela sua estética, pela própria presença no mundo produtos sem inocência, simbolizadores de ideologia, são coisas não ingênuas tal como sustenta Lukács na mencionada obra a ideia de que não há ideologia ingênua não existindo, então, portador estético mercantil assim também.

17 Como exemplo leia o caso da Polônia onde no dia 13 de junho o governo acabou com a garantia das 8 horas de trabalho, direito conquistado em 1919. O motivo: a Polônia se torna mais "competitiva" para os capitalistas que quiserem explorar seus trabalhadores (citado em www.resistir.info acessado no dia 15 de setembro de 2013). 


\section{Trabalhonecessário}

Issn: 1808 - 799X

ano 11, no $17-2013$

Por esse meio a estética do capital nos educa, uma educação estética feita por milhões e milhões de mercadorias, por suas cores, formas, sabores, sutileza e a violência dessa mesma educação. Violência tendo-se em conta que o mundo formado pelas coisas do capital é produto das decisões de classe com centralização das mesmas para a acumulação de mais capital. $O$ resultado é uma estética não formada pela educação transformadora das pessoas em sua capacidade crítica, mas estética imposta pelo mercado como lócus do encontro dos desejos e olhares. Estética não auto-desenvolvida, mas desenvolvida para nós pelo capital em suas relações de classe.

\section{O capital: estética e jogo de esconde-esconde}

A produção de uma estética própria ao capital cumpre dois papéis. Um deles delineado anteriormente de realizar a produção e como consequência educar a sociedade, educar o mundo pela sua estética. O outro papel é essa educação ser poderosa ideologia em um jogo de esconde, um esconder pela estética. Contradição aparente, pois se esconde através do que se vê. Usemos para isso uma metáfora:

Bem ali, no lugar mais fedorento de todo o reino, foi que nasceu Jean-Baptiste Greouille, a 17 de julho de 1738. Era um dos dias mais quentes do ano. O calor pairava como chumbo por sobre o cemitério e empurrava para as ruas vizinhas os gases da putrefação que cheiravam a uma mistura de melões podres e chifre queimado. Quando as dores começaram, a mãe de Grenouille estava numa peixaria da Rue aux Fers e escamava pescadas, as quais acabara de eviscerar. Os peixes, presumivelmente recolhidos do Sena naquela manhã, já fediam tanto que o seu fedor se sobrepunha ao dos cadáveres. Mas a mãe de Grenouille não percebia nem o cheiro dos peixes nem o dos cadáveres, pois o seu nariz era praticamente insensível a odores e, além disso doía-lhe o corpo, e a dor tirava-Ihe toda a sensibilidade para as sensações externas. Queria só uma coisa: que a dor cessasse, e deixar para trás o quanto antes o horror do parto. Era o seu quinto. Os quatro anteriores ela havia resolvido ali na peixaria, e os quatro haviam nascido mortos ou semimortos, pois a carne ensanguentada que dela saíra não se diferenciava muito das vísceras dos peixes que já estavam atirados pelo chão, e também não vivia mais muito tempo, e à noite era tudo jogado junto em carretas e levado para 0 cemitério ou lá para baixo no rio. Assim deveria ocorrer também hoje (SÜSKIND, s/d, p. 6-7). 


\section{Trabalhonecessário}

Issn: 1808 - 799X

ano 11, no $17-2013$

Mas sabemos pelo livro de Süskind que não ocorreu. Pelo contrário, JeanBapstiste Grenouille nasceu quase que amaldiçoado por um estranhíssimo dom: uma capacidade miraculosa de perceber cheiros, distinguir matizes, segui-los e diferenciá-los como se fossem linhas melódicas em um complexo mundo contrapontístico. Ascensão e descenso de vozes no contraponto eram a mesma coisa que os cheiros para ele: uma espécie híbrida de Bach e Mozart em um nariz. Não precisamos contar toda a história. Sabemos encontrar sua realização como perfumista, começando na "maior área de odores do mundo" e que "estava a seus pés: Paris." Grenouille é comparado a um carrapato que vive tempos a fio e repentinamente desperta. E assim foi sua ida para Paris (SÜSKIND, s/d, p. 35).

Para nosso propósito, essas passagens são sintomáticas e ilustram metaforicamente nosso objeto. Fizemos observação anterior sobre os cheiros e sua tentativa comercial de fazê-los chegar ao paladar pelo olhar. Neste caso usamos as imagens do romance de Süskind para chegar aos cheiros, odores putrefatos e, na sequência, à alta capacidade do "carrapato" Grenouille de discernir matizes e sutilezas desses odores todos, especialmente em meio tão abjeto. Insistência em "carrapato", não só pelo constante uso da imagem no romance, mas por ser o resultado a se desvendar na metáfora a qual buscamos. Imagens a revelar outros sentidos, os sentidos do cheiro e da náusea que a acompanha. Náusea que é sensação imediatamente forte diante da podridão descrita e elemento da própria imagética do cheiro: impossível não sentir tais cheiros de chifre queimado, melões podres, cemitério a exalar gases pesados como chumbo, vísceras de peixes quase apodrecidos, sem que todos remetam à morte, decomposição, vida extinta. $O$ cheiro só se pode ligar a tal imagética pelo saber a que representam, e tal representação é o resultado da linguagem.

A metáfora ganha substância para nós. O mundo das coisas do capital fará uma educação estética para esconder a sua sombra, esconder seus melões podres, as vísceras de peixe e o peso plúmbeo do ar. O jogo de esconde-esconde do capital perpetua sua violência por outros caminhos. Esconde sua realidade 


\section{Trabalhonecessário}

Issn: 1808 - 799X

ano 11, no $17-2013$

pútrida (permanecendo com as metáforas) através dos belos produtos do consumo, dos milhões de coisas e mais coisas, mercadorias marcadas para formar uma vida de objetos ao nosso redor e não uma vida nossa sobre os objetos.

A náusea desse mundo só pode surgir em um despertar de "carrapato". Não como Grenouille, que acaba por se entregar à pura manipulação; um despertar completamente distante de qualquer espécie de revelação ou "nirvana". Tal despertar está próximo do êxtase e ainda que cumpra em algum momento do desenvolvimento intelectual a sua função, uma catarse, ele deve prosseguir em busca dos elos de uma totalidade construída, produzida e montada pelo capital. É a realidade pelo e para o capital na qual bilhões de seres humanos são tomados apenas como elementos para serem levados a perceber e sentir apenas odores suaves, nunca sua situação mais abjeta entre os melões podres ${ }^{18}$. Pela produção infinita de coisas belas, coisas-mercadorias o capital produz ideologia pela linguagem simbólica e esconde por sob sua "beleza" tudo que não deve ser visto: as relações de classe, as relações de trabalho, a hiper-exploração do trabalho, o estresse humano, a depressão e a necessidade de psicotrópicos ou as drogas pesadas (TÜRCKE, 2010), a quantidade enorme de horas a se trabalhar para comprar o enorme mundo estético posto em torno da sociedade, a marginalização

\footnotetext{
18 Alguns desses bilhões efetivamente sentem o cheiro dos "melões podres" por serem descartados, experimentarem a si mesmos como peças facilmente substituíveis, e pouco importa que enxerguem o engodo a sua frente. Exemplos são os cerca de 1 bilhão de pessoas que passam fome pelo mundo segundo dados da FAO, ou os cerca de 2 bilhões que estão longe do padrão de consumo energético típico do capital com diferenças locais, claro. Isso nos lembra a fala do ator britânico falecido em 2011, Pete Postlethwait, no filme O Jardineiro Fiel, de Fernando Meirelles, interpretando o Dr. Lorbeer ao dizer que "o mundo estupra a África". Para esses o capital pode ser cru e não esconde seu pesado odor fétido de chumbo. Existe neste ponto muito mais do que uma metáfora, mas um fato absolutamente marcante em sua realidade: o capital potencializa-se globalmente em sua expansão, praticamente inesgotável em sua mobilidade pelo espaço do mundo. No entanto não consegue e nem mesmo pode acabar com esse imenso exército industrial de reserva em escala mundial deixando-os, todos esses corpos, a apodrecer na miséria total e absoluta. $O$ capitalismo não realizou suas promessas e simplesmente agoniza sendo estes miseráveis os primeiros a sentir sua tragédia.
} 


\section{Trabalhonecessário}

Issn: 1808 - 799X

ano 11, no $17-2013$

humana crescente, as "pessoas cinza"19 misturadas, camufladas pelas cidades para não serem vistas, etc. Enfim, o olhar ao qual fizemos referência anteriormente como olhar mediado pelo capital e a fantasia produzida pelo mesmo, passa a ser um olhar cego para outras estéticas e outros espaços. Um reino de fantasia é produzido e com isso uma educação estética violenta e da qual se deve deslindar.

Por esse motivo julgamos essencial a análise dos processos culturais e suas formas de linguagem. As condições dos trabalhadores, de todos os trabalhadores submetidos diretamente ou indiretamente ao capital - sentindo ou não o cheiro maior ou menor dos melões podres - não pode ser revelada criticamente sem pensar na completude de sua existência. Esta existência submetida, então, a todos esses processos intricados de sujeito do capital nas coisas e o objeto nas pessoas ${ }^{20}$ tornando-se sujeitos em uma e apenas uma situação: pelo desejo da estética do capital, consumir coisas e mais coisas. A análise dessas situações revela todo esse processo existencial-cultural e deve possuir capacidade da crítica estética pela educação crítica.

Para sermos claros e fugirmos de qualquer universal abstrato: educação crítica é aquela articuladora de todos os momentos do real, busca cada determinação entre os vários processos, entende as mediações que ligam as determinações de tal forma a conseguir entender complexas conexões entre todas as instâncias componentes da realidade - a política, a cultura, a ideologia,

\footnotetext{
${ }^{19}$ Esta referência às "pessoas cinza" deve-se a Edilena Malta e a uma discussão em torno disso no dia 28 de setembro de 2008 no Cine-Teatro de Itápolis por ocasião da apresentação da peça Ao Revés do Papel do grupo teatral Preto no Branco da cidade de São Carlos com os atores e diretor do grupo no contexto do Mapa Cultural Paulista, evento da Secretaria de Cultura do Estado de São Paulo. O paralelo metafórico pode se estabelecer com os soldados que não desejam ser vistos e usam fardas e camuflagem nos rostos. No caso das ruas, as pessoas tornam-se cinzas, confundidas com a rua e só vistas quando querem. Forma também de fugir à polícia ou ao menos tentar.

${ }^{20}$ Processo de reificação tratado por uma quantidade enorme de intelectuais. Mostramos em nosso texto como se evidenciou que essa reificação tem outras conexões: a ideológica, ou seja, não é apenas um embrutecimento, mas uma forma de educar e transferir o olhar para outras "paragens", outras estéticas de forma nunca antes imaginada na sociedade mediada pelo capital.
} 


\section{Trabalhonecessário}

Issn: 1808 - 799X

ano 11, no $17-2013$

as condições de produção, o modo de produção e suas bases duras, etc. Entendimento que não pode escapar para completar sua carga crítica e educadora com a superação das relações de classe e de produção; não pode escapar da compreensão que o capital só se move, tem determinada dinâmica pela ação de classes hegemônicas e, por fim e resultado dessa educação, só conseguirá educação a emancipar contra a estética do capital através da emancipação das condições de produção por meio também da crítica cultural e existencial incluindo a estética do capital e sua específica forma violenta de educação por meio de seu olhar cegante, ofuscador de tudo a não ser olhado a menos por desejo expresso dessa mesma razão de produção, concentração e centralização das riquezas.

Entrar-se-ia pelos domínios da ética a continuar nesta toada. Em outros termos, passaríamos a outra etapa proponente da crítica, a etapa da busca de mediações possíveis da superação do capital. Neste caso, ou seja, uma dessas mediações possíveis seria contrapor à educação deseducadora do capital uma educação referida anteriormente como emancipatória. E tema possível para outros ensaios e, principalmente, ações, práxis em busca dessa emancipação, atacando diretamente as estruturas das relações de classe e sua forma de produção, acumulação e centralização da riqueza sob o capital.

Dentro desse campo educacional uma das potencialidades seria demonstrar seu dinamismo e dialética inerentes como elemento em complexo maior que é o da ideologia. Dialética e dinamismo que lhe permitem descobrir frinchas no real, rupturas e aberturas de transformação consciente e da consciência. Dentro da sociedade do capital uma das trilhas na busca das mediações possíveis seria processo educacional enfatizador de como toda sociedade constrói totalidades estruturadas sobre todos os domínios da realidade. $\mathrm{Na}$ sociedade do capital essa totalidade estruturada é mais intensa no sentido de que a lógica da produção, reprodução e acumulação de capital busca todos os "poros" sociais para continuar seu processo cíclico e tendente às crises bem 


\section{Trabalhonecessário}

Issn: 1808 - 799X

ano 11, no $17-2013$

como à exposição de sua própria irracionalidade. Educação emancipatória devendo, então, expor essa lógica totalizante e totalizadora; educação podendo só extrair sua matéria, forma e conteúdo do entendimento do funcionamento, dos meandros, das "malícias" e sons encantadores presentes dentro da totalidade de uma sociedade concreta e, em nosso caso, a sociedade do capital ${ }^{21}$. Assim:

A totalidade concreta como concepção dialético-materialista do conhecimento do real [cuja dependência face à problemática ontológica da realidade já ressaltamos repetidas vezes] significa, portanto, um processo indivisível, cujos momentos são: a destruição da pseudoconcreticidade, isto é, da fetichista e aparente objetividade do fenômeno, e o conhecimento da sua autêntica objetividade; em segundo lugar, o conhecimento do caráter histórico do fenômeno, no qual se manifesta de modo característico a dialética do individual e do humano em geral; e enfim o conhecimento do conteúdo objetivo e do significado do fenômeno, da sua função objetiva e do lugar histórico que ela ocupa no seio do corpo social. (KOSIK, 2002, p. 61, grifo no original).

${ }^{21}$ Sobre o conceito de civilização do capital, bem mais do que sociedade do capital, sua lógica totalizadora de tal modo que o capital é "uma totalidade mais total" e o irracionalismo atual ver o livro Sociedade, Natureza e Energia: condições estruturais e superestruturais de produção no capitalismo tardio (DOTI, 2008). 


\section{Trabalhonecessário}

Issn: 1808 - 799X

ano 11, no $17-2013$

\section{Referências:}

ADORNO, Theodor; HORKHEIMER, Max. Dialética do esclarecimento: fragmentos filosóficos. 2 ed. Tradução de Guido Antonio de Almeida. Rio de Janeiro: Jorge Zahar, 1986.

BAUDRILLARD, Jean. 0 sistema dos objetos. 4 ed. São Paulo: Perspectiva, 2006.

BERMAN, Marshall. Tudo que é sólido desmancha no ar: a aventura da modernidade. $17^{a}$ reimpr. São Paulo: Companhia das Letras, 2000.

DOTI, Marcelo Micke. Sociedade, natureza e energia: condições estruturais e superestruturais de produção no capitalismo tardio. São Paulo: Editora Edgard Blucher, 2008.

FRY, Dennis. Homo loquens: o homem como animal falante. 1 ed. Rio de Janeiro: Zahar Editores, 1978.

HAUG, Wolfgang Fritz. Crítica da estética da mercadoria. São Paulo: Editora da Unesp, 1997.

KOSIK, Karel. Dialética do concreto. 7 ed. Rio de Janeiro: Paz e Terra, 2002.

LUKÁCS, Georg. El asalto a la razón: la trayectoria del irracionalismo desde Schelling hasta Hitler. 3 ed. Barcelona-México: Edições Grijalbo, 1972.

MARX, Karl; ENGELS, Friedrich. A ideologia alemã (I - Feuerbach). 5 ed. São Paulo: Hucitec, 1986.

PINKER, Steven. 0 instinto da linguagem: como a mente cria a linguagem. 2 ed. São Paulo: Martins Editora, 2004.

SARTRE, Jean-Paul. A náusea. Rio de Janeiro: Record; São Paulo: Altaya, s/d.

SÜSKIND, Patrick. O perfume. Rio de Janeiro: Record; São Paulo: Altaya, s/d.

TÜRCKE, Cristoph. Sociedade excitada: filosofia da sensação. 1 ed. Campinas: Editora da Unicamp, 2010.

Data de recebimento: 04/10/2013

Data de aprovação: 23/10/2013 